\title{
AN EXEGESIS PAPER ON IGNATIUS TO EPHESIANS 18-19
}

\author{
Philip Suciadi Chia' ${ }^{1)}$, Juanda ${ }^{2}$ \\ 1) Southern Baptist Theological Seminary - Kentucky USA \\ E-mail: pchia275@students.sbts.edu \\ ${ }^{2)}$ Evangelical Theological Seminary of Indonesia - Surabaya \\ E-mail: juanda@sttii-surabaya.ac.id
}

\begin{abstract}
There are 7 letters written by Ignatius from Antioch, while traveling to Rome. One of them is the church at Ephesus which consists of 21 chapters. In this letter, Ignatius urges these Christians to be in unity with their bishop, because the Docetists were denying the true humanity of Christ. We also find here the unique emphasis on Jesus Christ as the one physician and the Eucharist as 'the medicine of immortality'. Furthermore, by insisting on the virgin birth to explain Jesus' existence as the Christ, Ignatius makes a vigorous antidocetic statement.

In this exegetical study, the writer will specifically examine only chapters $18-19$, to find the meaning of the writing of these two chapters, which are related to suffering through self-sacrifice. Ignatius speaks in self-deprecating terms as he gives his life as a selfoffering. By the world, he is regarded as a criminal but in God's plan of salvation (oikonomia) his sufferings benefit the church. Ignatius merely makes this more explicit with his remark that what God had prepared 'had its beginning'. He probably would have gone on to stress the passion as the culmination of God's plan, though he was also conscious of the fact that Satan's power had not even yet been completely destroyed.
\end{abstract}

Keywords: Ignatius of Antioch, Jesus Christ, Ephesians Letter

\section{INTRODUCTION}

Ignatius' address to the Ephesians is an enrichment of the common Hellenistic form: so-and-so to so-and-so greeting. The use of the term 'greeting' ( $\chi \alpha \iota \rho \varepsilon ı v)$ rather than 'grace and peace' or any of other

${ }^{1}$ Francis Xavier J. Exler, The Form of the Ancient Greek Letter: A Study in Greek Epistolography
Judaized and Christianized forms of greeting in the NT is one of many indications that Ignatius is closer to pagan epistolary models and reworks them independently. ${ }^{1}$

(Washington D.C: Catholic University of America, 1923), 63. 
Theological Journal Kerugma

E-ISSN: 2622-1039

P-ISSN: 2621-8038

Ephesus was a large and productive commercial center whose religious life centered around the worship of Artemis (Diana). We learn from this letter that Onesimus was the bishop of Ephesus during Ignatius' day (1:2).

In this letter, Ignatius urges these Christians to be in unity with their bishop (4:2), because the Docetists were denying the true humanity of Christ $(7: 2 ; 10: 2 ; 16: 1$, $2 ; 18: 2 ; 19: 1 ; 20: 2)$. We also find here the unique emphasis on Jesus Christ as the one physician (7:2) and the Eucharist as 'the medicine of immortality' $(20: 2) .^{2}$ This paper, however, will discuss Ephesians 1819 only.

\footnotetext{
${ }^{2}$ Kenneth J. Howell, Ignatius of Antioch: A New Translation and Theological Commentary (Zanesville: CHResources, 2008), 55.
} 


\section{Translation}

\begin{tabular}{|c|c|c|}
\hline Verse & Greek Text & English Translation \\
\hline $18: 1$ & 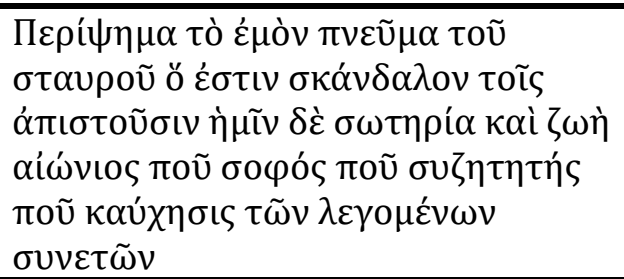 & $\begin{array}{l}\text { My spirit is a humbleness of the cross which } \\
\text { is the stumbling block to unbelievers, but } \\
\text { salvation and eternal life for us. Where is the } \\
\text { wise? Where is the debater? Where is the } \\
\text { boasting of those who are said to be } \\
\text { intelligent? }\end{array}$ \\
\hline 18:2 & 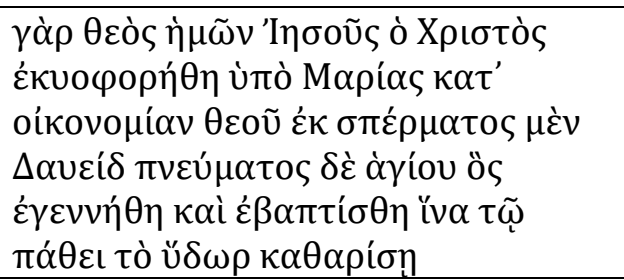 & $\begin{array}{l}\text { For our God, Jesus the Christ, was conceived } \\
\text { by Mary according to plan of God, on one } \\
\text { hand from the seed of David, and on the other } \\
\text { hand (the seed) of Holy Spirit. He was born } \\
\text { and baptized so that by his suffering, he } \\
\text { might purify the water. }\end{array}$ \\
\hline 19:1 & 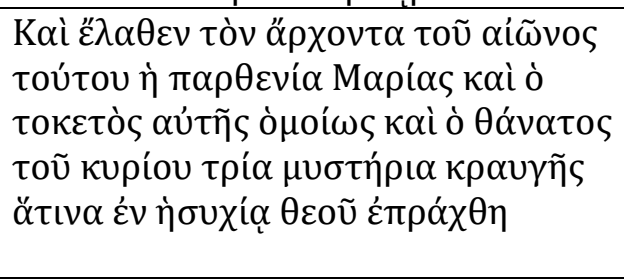 & $\begin{array}{l}\text { And the virginity of Mary and her giving birth } \\
\text { in the same way also the death of the Lord } \\
\text { escaped the notice from the ruler of this } \\
\text { world. Three mysteries (to be) loudly } \\
\text { acclaimed, which were accomplished in the } \\
\text { silence of God. }\end{array}$ \\
\hline 19:2 & 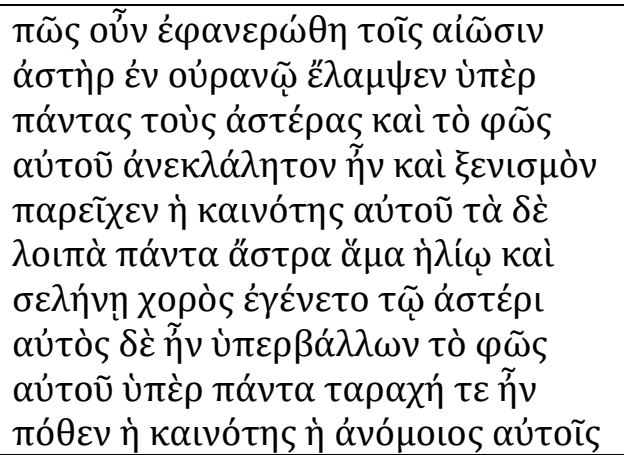 & $\begin{array}{l}\text { Therefore, how was it manifested to the } \\
\text { hosts? A star shone forth in heaven brighter } \\
\text { than all the stars and its light was } \\
\text { inexpressible, and its novelty was showing } \\
\text { astonishment. And the rest of the stars, along } \\
\text { with the sun and the moon, formed a chorus } \\
\text { for that star, and its light exceeded than them } \\
\text { all and there was perplexity (as to) whence } \\
\text { (came) this novelty (so) unlike them. }\end{array}$ \\
\hline 19:3 & 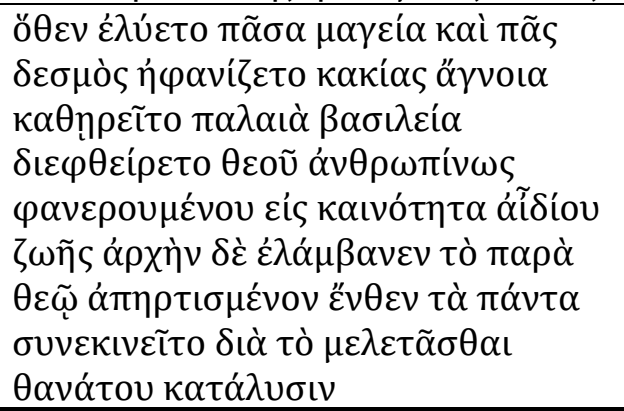 & $\begin{array}{l}\text { Therefore, all magic and every bondage were } \\
\text { destroyed; the ignorance of evil was } \\
\text { abolished, the old kingdom was perished, God } \\
\text { being revealed as human to bring newness of } \\
\text { eternal life, and what had been prepared by } \\
\text { God had its beginning; hence all things were } \\
\text { disturbed because the destruction of death } \\
\text { was being worked out. }\end{array}$ \\
\hline
\end{tabular}




\section{Commentary}

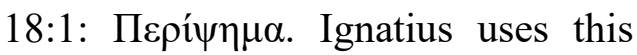
word twice in this letter (8:1 and 18:1). This word occurs in three meanings: (a) 'offscouring', (b) 'scapegoat' (a Greek custom is attested of sacrificing a social outcast to purify the community), (c) 'your humble servant' (a term of polite selfeffacement). ${ }^{3}$

Hesychius in his lexicon connects $\pi \varepsilon \rho \iota \psi \eta \mu \alpha$ with $\alpha \nu \tau \imath \psi v \chi 0 v$ and other sacrificial terms. ${ }^{4}$ A possible background for

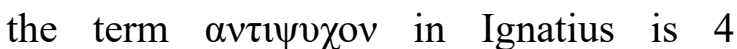
Maccabees $(6: 29 ; 17: 21)$ where it refers to the death of the Maccabean martyrs as vicarious expiation. ${ }^{5}$ Holmes translates as 'humble sacrifice'. Ehrman translates this as 'sacrificial offering'. 6

Ignatius speaks in self-deprecating terms as he gives his life as a self-offering. By the world, he is regarded as a criminal but in God's plan of salvation (oikonomia) his sufferings benefit the church. ${ }^{7}$

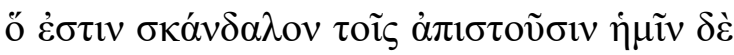

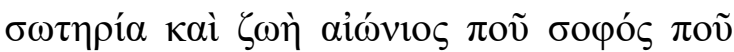

\footnotetext{
${ }^{3}$ William R. Schoedel, Ignatius of Antioch (Minneapolis: Fortress Press, 1985), 63-64.

${ }^{4} \mathrm{BAG}, 659$.

${ }^{5}$ Othmar Perler, "Das vierte Makkabäerbuch, Ignatius von Antiochien und die ältesten Märtyrerberichte," Rivista di archeologia Cristiana 25 (1949), 51-52.

${ }^{6}$ Bart Ehrman, The Apostolic Fathers (Cambridge, MA: Harvard University Press, 2003).

${ }^{7}$ Howell, Ignatius of Antioch, 62.

${ }^{8}$ For it is written, "I will destroy the wisdom of the wise, and the discernment of the discerning I will
}

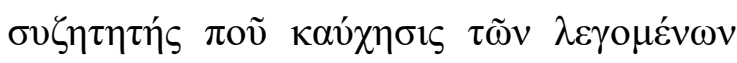

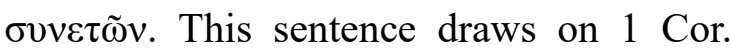
1:19-23. ${ }^{8}$ The key element of this sentence is the cross which is both a stumbling block and a salvation.

Ignatius also employs this theme to challenge to the intelligent and he turns back to the incarnation in the following sections to develop his arguments. For Christ's birth and passion were closely related in his mind, and it is likely that the full reality of them was denied by the Docetists of those days. ${ }^{9}$

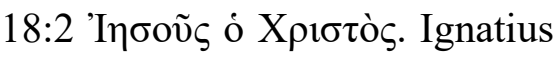
generally prefers simply 'Jesus Christ', which occurs about a hundred times and which apparently functions as a double name. It is very likely, then, that is derives from an older (perhaps adoptionist) tradition that still reflects a sensitivity to the name 'Christ' as a title. Also, the reference to Christ as 'our God' seems distinctively to Ignatius (Eph. 15:3; 18:2). ${ }^{10}$

Oikovouíav is a word used by Paul and many later church fathers,

thwart." Where is the one who is wise? Where is the scribe? Where is the debater of this age? Has not God made foolish the wisdom of the world? For since, in the wisdom of God, the world did not know God through wisdom, it pleased God through the folly of what we preach to save those who believe. For Jews demand signs and Greeks seek wisdom, but we preach Christ crucified, a stumbling block to Jews and folly to Gentiles,

${ }^{9}$ Schoedel, Ignatius of Antioch, 84.

${ }^{10}$ Ibid, 39. 
especially Irenaeus. It denotes the plan of salvation or God's design for the redemption of the human race.

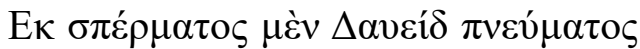
$\delta \dot{\varepsilon} \alpha \gamma$ íov. This is a description formula of Christ as being 'of the seed of David and of the Holy Spirit'. This formula is preserved by Paul (Rm. 1:3-4). ${ }^{11}$

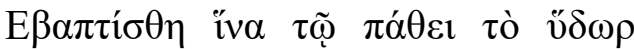

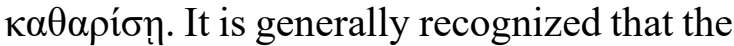
water was purified by Christ's baptism in the Jordan was known to both the orthodox and the heterodox.

It is likely that the old near eastern mythology of the defeat of the dragon of the deep (alive in Odes So. 22:5; 24:1-4) lies behind this theology. The idea is expressed in classical form by Cyril of Jerusalem who states that 'to crush the heads of the dragon' (Ps. 73:13) Christ 'descended into the waters and bound the strong one' so that we might receive the "power to tread upon serpents and scorpions' (Catech. 3:11). ${ }^{12}$ Therefore, Jesus defeated the dragon of the deep by his suffering.

\footnotetext{
${ }^{11}$ Concerning his Son, who was descended from Davidaccording to the flesh and was declared to be the Son of God in power according to the Spirit of holiness by his resurrection from the dead, Jesus Christ our Lord.

${ }^{12}$ Jean Daniélou, The Theology of Jewish Christianity: A History of Early Christian Doctrine before the Council of Nicaea, vol. 1 (London: Darton, Longman and Todd; Chicago: Regnery, 1964), 224-227.
}

19:1 H $\pi \alpha \rho \theta \varepsilon v i ́ \alpha$ Mapías. It does not mean that Ignatius maintains the virginity of Mary. The text stresses the fact that Joseph continued as Mary's husband externally, telling no one of the virgin birth, and that the birth itself took place while he and Mary were alone.

Similarly, in an interpretation of Ignatius' words, Origen (Hom. In Luc. 6) says that thanks to Joseph, Mary passed as a married woman and so escaped the notice of Satan. Also, Mary's virginity is treated merely as giving assurance that the human Jesus was pure and capable of receiving the non-material Christ when it descended upon him. By insisting on the virgin birth to explain the being of Jesus as the Christ, Ignatius is making a vigorous anti-docetic statement. $^{13}$

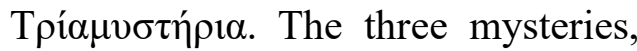
Mary's virginity and her childbearing 'in the same way also' the Lord's death, clearly break down into two groups and as such correspond to the birth and the baptism as death at the end of the previous section $(18: 2){ }^{14}$

\footnotetext{
${ }^{13}$ Schoedel, Ignatius of Antioch, 85.

14 The twin theme of "birth and parturition" was suggested by Isa. 7:14 ("a virgin shall conceive and bear a son"), as Tertullian (Carn. Christ 23:1-2) indicates. The theme is also connected by Tertullian with a prophecy about the one "who bore yet did not bear" (23:6). This saying is much repeated in later sources, and the thought is reflected in Asc. Is. 11:13-14. Alfred Resch, Agrapha (TU 30; Leipzig: Hinrichs, 1906), 305-306.
} 
Thus, there can be no emphasis on the number three. Elsewhere the expression 'in the same way also' emphatically affirms the relevance of what has just been said to another item. Therefore, Ignatius is not simply listing the events of Jesus' life in chronological order; and if it seems best, we are free to think that he goes on in 19:2-3 to comment on the birth of Christ in particular. Three things favor this solution:

a. According to Eph. 20:1, Ignatius regards himself as just 'getting into' $(\eta \rho \xi \alpha \mu \eta v)$ his exposition of the divine 'plan'; and it is likely that he began at the beginning with the incarnation, especially since he links the birth of Christ and the divine 'plan' so closely in Eph. 18:2.

b. The expression 'God being revealed as human' in Eph. 19:3 may have in view the earthly epiphany of Christ as a whole, but surely refers to the incarnation in particular (Mag. 8:2); in any event, the present tense of the participle indicates that Christ's manifestation in human form is thought of as contemporaneous with the shattering of the powers of evil; and such a statement seems out of place if Christ has just been described as having ascended and left this world behind. ${ }^{15}$

\footnotetext{
${ }^{15}$ Hans-Werner Bartsch, Gnotisches Gut und Gemeindetradition bei Ignatius von Antiochien (Gütersloh: Bertelsmann, 1940), 141, 150-151.

${ }^{16}$ Schoedel, Ignatius of Antioch, 85.
}

c. The birth and the passion were clearly linked in Ignatius' mind, and here the older part of the Ascension of Isaiah may help us fill out the picture that Ignatius has left incomplete; for after the future descent of the Son is announced in heaven (9:1213), the angel says, "and the god of that world will stretch forth his hand against the Son and they will lay hands on him and crucify him on a tree without knowing who he is; so his descent, as you will see, is hidden from the heavens so that it remains unperceived who he is" $(9: 14-15){ }^{16}$

Hov $\chi 1 \alpha$. This is usually taken either as a reference to the mysterious purposes of God brought to fulfillment in God's good time or as another indication of a growing emphasis on God's transcendence in Ignatius' theology. The latter in turn has been traced to the influence of Gnosticism. $^{17}$

Both solutions require us to take $\varepsilon \pi \rho \alpha \chi \theta \eta$ 'were done' as having to do with things effected within the purpose or sphere of the divine. But the use of the same verb in Mag. 11 ( $\pi \rho \alpha \chi \theta \varepsilon v \tau \alpha)$ and Sm. 4:2 $(\varepsilon \pi \rho \alpha \chi \theta \eta)$ to refer to the same events under discussion here suggests that Ignatius is speaking of the birth and passion as

\footnotetext{
${ }^{17}$ Heinrich Schlier, Religionsgeschichtliche Untersuchungen zu den Ignatius briefen (BZNW 8; Giessen: Töpellman, 1929), 27; Mag. 8:2.
} 
historical events not openly commented on by God. 'In the silence of God' then, means 'while God remained silent' just as a woman is counselled to learn while keeping silent in 1 Tim. 2:11. ${ }^{18}$

Yet as in Eph. 15:2, these deeds without words speak volumes. With this in mind, the paradoxical expression 'three mysteries of a cry' and the antithesis between such revelations and the silence of God become intelligible. The unheralded events of salvation cry out their meaning to those who are able to grasp their significance. ${ }^{19}$

19:2. The question that follows apparently means, "if the events of salvation were hid from the evil one, how then did he and his hosts ${ }^{20}$ come to level their animosity at Christ?" What arouses the envy of the powers in the interpolation of the Ascension of Isaiah 11:18-19 are the signs and wonders performed by Jesus. Ignatius finds a still earlier cause for their alarm in events at the time of the incarnation. The star

\footnotetext{
${ }^{18}$ If any deeper background for the expression seems required, the relevant parallel is Wis. 18:1415 where we are told that all was in silence as the divine word descended from heaven. Hans Lietzmann, The beginnings of the Christian Church (New York: Scribner, 1937), 323-324; Allen Cabaniss, "Wisdom 18:14: An Early Christmas Text," VC 10 (1956), 97-102.

${ }^{19}$ Schoedel, Ignatius of Antioch, 90.

${ }^{20}$ Although the word $\alpha \omega v \varepsilon \varsigma$ elsewhere in Ignatius means "ages" (see on Eph. 8:1), it seems more likely to refer to supernatural beings here. This use of the term need not be Gnostic. "Lord of Lords, God of gods, King of kings, and God of the hosts
}

indicated to the powers that something threating was afoot, but they did not assess its significance accurately since they were unaware of the startling miracles that surrounded the birth of Christ. ${ }^{21}$

What, then, is the relation between the star and the theme of the disturbance of the powers? Perhaps Ignatius has taken a fragment of a descent or ascent theme (the disturbance) and under the influence of the Epiphany star transformed it into a heavenly event parallel to the birth of Christ. But it seems at least as likely that the theme of the disturbance of the powers developed first in connection with the star and later came to be applied in other contexts. ${ }^{22}$ The divine sign that marked the beginning of the hidden career of Christ came to be replaced by the hidden descent of Christ himself.

19:3. What follows allows us to be somewhat more precise. We are told that with the appearance of the new star all magic, every bond, ignorance, and the old kingdom begin to break up. It is presumably

seems to be original text of an old section of 1 Enoch 9:4. R. H. Charles, The Book of Enoch or 1 Enoch (Oxford: Clarendon, 1912), 20.

${ }^{21}$ Schoedel, Ignatius of Antioch, 91.

22 It may be that the "disturbance" of Herod and "all Jerusalem with him" (Matt. 2:1-12) represents an application on the historical plane of the disturbance of the stars. For, as the First Apocalypse of James will say, Jerusalem "is the dwelling place of many archons" ([NHC 5] 25, 18-19). Herod's unsuccessful effort to slay Christ may also mirror the failure of the evil powers to have their way with the child. 
the heavenly bodies that are here said to lose their grip on humankind.

Astrology and magic were closely associated in popular culture (Apuleius Golden Ass 2:5, 11:12), and both contributed to the plain person's sense of being oppressed by occult powers. The Eastern magi in particular were conceived of as devoted to both, ${ }^{23}$ and it is likely that Matthew represented a common view of Christians when he associated the tradition of the star with the subordination of the magi to the new faith.

Thus, Tertullian (Idol. 9) finds it significant that the magi first announced the birth of Christ and explains in this connection that the fallen angels (Gen. 6 and 1 Enoch 6) discovered astrology and introduced magic. Similarly, Origin (Cels. $1: 60)$ traces the weakening of the demonic powers responsible for magic to the appearance of the Epiphany star. ${ }^{24}$

$\Delta \varepsilon \sigma \mu \mathrm{s}$. The expression 'every bond' may refer in this context either to magical spells ${ }^{25}$ or more generally to the constraints of evil powers ${ }^{26}$ or of fate. ${ }^{27}$ The term 'ignorance' $(\alpha \gamma v o 1 \alpha)$ is used with some frequency in early sources to describe the human state apart from God's grace. ${ }^{28}$

Ignatius notes near the end of 19:3 that the star marked only the 'beginning' of the fulfillment of God's purpose. All the preceding verbs are imperfects and should be understood as inceptives - magic 'began to be destroyed', every bond 'began to vanish', and so forth.

Ignatius merely makes this more explicit with his remark that what God had prepared 'had its beginning'. He probably would have gone on to stress the passion as the culmination of God's plan (Sm. 5:3), though he was also conscious of the fact that Satan's power had not even yet been completely destroyed (Eph. 13:1).

\footnotetext{
${ }^{23}$ Joseph Bidez and Franz Cummont, Les mages hellénisés 2 vols (Paris: Les belles lettres, 1938), 1: 131-150, 193-198; 2243.

${ }^{24}$ Schoedel, Ignatius of Antioch, 94.

${ }^{25}$ Plato Resp. 2, 364c; PGM 4.296, 336; Plotinus Enn. 4.4.40; Iamblichus De myst. 3.27.

${ }^{26}$ Luke 13:16; Hippolytus Comm. In Dan. 4:33; Odes Sol. 21:2; 25:1; 42:16; Trim. Prot. (NHC 13) 41:4-5; 44: 14-17.
} 


\section{REFERENCE}

[1] Bartsch, Hans-Werner.Gnotisches Gut und Gemeindetradition bei Ignatius von

Antiochien.Gütersloh: Bertelsmann, 1940.

[2] Bidez, Joseph and Franz Cummont, Les mages hellénisés 2 vols. Paris: Les belles lettres,

1938.

[3] Cabaniss, Allen. "Wisdom 18:14: An Early Christmas Text," VC 10, 1956.

[4] Charles, R. H. The Book of Enoch or 1 Enoch. Oxford: Clarendon, 1912.

[5] Chia, P. S., \& Juanda, J. (2020). Suffix Study $1 \alpha$. Journal KERUGMA, 3(2), 1-4.

[6] Daniélou, Jean.The Theology of Jewish Christianity: A History of Early Christian Doctrine

before the Council of Nicaea, vol. 1.

London: Darton, Longman and Todd; Chicago: Regnery,

1964.

[7] Ehrman, Bart.The Apostolic Fathers.

Cambridge, MA: Harvard University Press, 2003.

[8] Exler, Francis Xavier J. The Form of the Ancient Greek Letter: A Study in Greek

Epistolography. Washington D.C: Catholic University of America, 1923.

[9] Howell, Kenneth J. Ignatius of Antioch: A New Translation and Theological Commentary.

Zanesville: CHResources, 2008.

[10] Lietzmann, Hans.The beginnings of the Christian Church. New York: Scribner, 1937.

[11] Perler, Othmar. "Das vierte Makkabäerbuch, Ignatius von Antiochien und die ältesten

Märtyrerberichte," Rivista di archeologia Cristiana25, 1949.

[12] Resch, Alfred. Agrapha. TU 30;

Leipzig: Hinrichs, 1906.
[13] Schlier, Heinrich.Religionsgeschichtliche Untersuchungen $\mathrm{zu}$ den Ignatius briefen. BZNW

8; Giessen: Töpellman, 1929.

[14] Schoedel, William R. Ignatius of Antioch. Minneapolis: Fortress Press, 1985.

[15] Till, Walter C. Die gnostischen Schriften des koptischen Papyrus Berolinensis 8502. Berlin:

Akademie-Verlag, 1955. 